\title{
The Capability Approach and Evaluation of the Well-Being in Senegal: An Operationalization with the Structural Equations Models
}

\author{
Felwine Sarr, Muhammad Ba \\ Gaston Berger University, Saint-Louis, Senegal \\ Email: felwine@gmail.com
}

How to cite this paper: Sarr, F. and Ba, M. (2017) The Capability Approach and Evaluation of the Well-Being in Senegal: An Operationalization with the Structural Equations Models. Modern Economy, 8, 90110.

http://dx.doi.org/10.4236/me.2017.81007

Received: November 19, 2016

Accepted: January 17, 2017

Published: January 20, 2017

Copyright (c) 2017 by authors and Scientific Research Publishing Inc. This work is licensed under the Creative Commons Attribution International License (CC BY 4.0).

http://creativecommons.org/licenses/by/4.0/

\begin{abstract}
This article uses the theoretical framework of the capabilities approach to offer a structural assessment model of well-being in the context of Senegal. To this end, we mobilize the Senegalese data (ESPS-II) and an evaluation space including basic and central capabilities of [1] and [2], which are: living conditions, education and health body, non-institutional support and good governance, on the one hand, and the three dimensions of well-being (economic well-being, life satisfaction and subjective well-being), on the other hand. With the modeling technique by structural equations: PLS-PM (Partial Linear Square-Path Modeling), we find that the estimation model of well-being has built good predictive quality. In addition, it shows that the basic capabilities (education, living conditions and health of the body) positively determine well-being (economic well-being, subjective well-being and life satisfaction). Also, economic well-being and life satisfaction positively predict and cause subjective well-being. Contrariwise, non-institutional support and good governance do not significantly cause subjective well-being. Between these two capabilities, only good governance has a significant and positive effect on life satisfaction.
\end{abstract}

\section{Keywords}

Capabilities Approach, Well-Being, Structural Equations Models (SEM), Partial Linear Square-Path Modeling (PLS-PM)

\section{Introduction}

The aim of this article is to provide, in an exploratory framework, a structural model assessment of welfare based on the capability approach (labeled "CA" in this article) by applying it to data from a developing country: Senegal, and using 
a modeling technique that is the PLS-PM approach (Linear Partial Square-Path Modeling) family of structural equation modeling (SEM).

CA developed by [3] [4] [5], is not a theory that explains the poverty, inequality or welfare, but a flexible, multi-purpose approach that allows conceptualizing and measuring these phenomena [4] [6] [7] [8]. In this sense, the CA is a normative framework which proposes that the social organization and the individual states are assessed in accordance with the increased capabilities of individuals to do what they value [9]. The two main concepts of the conceptual basis of the CA are: capabilities (freedoms to accomplish) and functioning (achievements). The capabilities are defined as real freedoms (or ability) to perform statements and actions. The functioning is the many aspects of life that a person values and manifested by achievements in terms of doing and being. Their nature can be very basic to be healthy; have enough food; be preserved from premature death, etc. Or very complex to be happy; take part in the life of one's community; stay fit, etc. [10]. Thus, according to [5], the capabilities include, among others, all information on the combinations of functioning that a person can choose, i.e. its real freedom to enjoy values activities and states. The evaluation space offered by the capabilities approach is the real freedoms. In other words, the evaluation exercise does not focus on livelihoods, such as income, but on the real possibilities of living which individuals have [5]. However, due to its informational requirement and its methodological complexity, empirical applications of the capabilities approach have been questioned by some authors [11] [12] [13] [14] [15]. These will be dispelled by series of practical applications of this approach in different geographical contexts, on the assessment of poverty or welfare. Sen's approach is an open structure which is deliberately undefined and allows a user that takes into account the context of evaluation. Moreover, this is what makes its theoretical relevance along with its practical difficulty. This constitutes the major interest and the aspect which this work particularly deals with. Most studies concerning developing countries assess the well-being of individuals and their level of poverty; considering mainly the income or the different assets that they have as the basis of their assessment.

Consequently, the normative exercise that we propose involves conceptualizing and estimation of individual well-being, among others, in the context of Senegal. This is, to our knowledge, the first study of its kind in the Senegalese context. Moreover, in Senegal, most poverty studies have used the monetary approach (consumption or income) to study the determinants of living standards according to different socio-economic groups to which households belong [16][23]. Given the limit related to the one-dimensional approach [22], have attempted to use a multidimensional approach taking into account the assets of households and their access to infrastructure. In that same logic, [24] [25] [26] use the fuzzy set theory in the multidimensional framework by taking into account not only assets, infrastructure but also the dimensions such as education and health. Most of these works claim the CA as a theoretical framework, due to the nature of their welfare assessment in multidimensional spaces. Nonetheless, they 
carry in the low to accentuate the accomplishments or achievements, disregarding the achievement freedoms or capability. In addition, a gap in their models is related to the demonstration of a causal structure of poverty or well-being of all relevant dimensions. It is in this sense that modeling by structural equation has a great advantage over other statistical and econometric tools used in the implementation of the CA and the measure of well-being. MES allows, indeed, to measure capability as a latent variable; and to give the nature of the causal relationships between these variables. In addition, with the PLS-PM MES approach we have a fundamental contribution that the other models do not: the ability to have a prediction of a dimension from the different causal variables of the model.

The rest of the article is organized as follows. In the second section, we present a review of the empirical literature of the CA, by focusing on the work that has focused on the context of developing countries and use of MES. The third section presents the methodology for the application of CA. In the fourth section, we specify and estimate our empirical model and report our results. Finally, in the last section we discuss our results and conclude.

\section{Review CA Empirical Literature}

Sen [27], two years after Commodities and Capabilities, makes an application, one of the first of CA, comparing the ranking of countries according to some operations from that based on the income approach. It will follow another application based on the macroeconomic data that will calculate the HDI, whose CA is the theoretical framework [28]. In fact, the mid-90s mark the emergence of CA empirical literature, in large expansion today [29]-[34]. Most of these applications are for geographic context of Western countries (Italy, Belgium, England...), Asia and Latin America. The few CA applications, to our knowledge, whose context is African countries are made in South Africa [35] [36] [37]; Nigeria [38] and Senegal [26].

However, this first part of the empirical literature is based on a measurement of functioning space, with the use of techniques such as the fuzzy set theory. It was only in the 2000s that has developed empirical literature measurement capabilities, especially with the use of SEM. In this statistic tool, capabilities are represented by the latent variables and are reflected in the operations that are manifest or observed variables. Kuklys [39] and Krishnakumar [33] are among other-the pioneers of this literature-in the context of developing countries. In the context of developing countries some evaluation efforts in the space of capabilities exist, but with a relatively low number of applications on the African continent.

Wagle [40] is among the first applications in this part of the empirical literature. With a sample of 625 households interviewed in the city of Kathmandu in Nepal, multidimensional poverty is estimated using: the economic well-being (the objective and subjective well-being), social capabilities and inclusion (economic inclusion, political and civic/cultural). The author chose three dimensions from the available literature on poverty, welfare economics, the CA and social 
inclusion approaches. He uses MIMIC (Multiple Indicators, multiple causes) approach of SEM, in particular the LISREL (SEM-CB) ${ }^{1}$ to estimate the capabilities and relationships with other dimensions of poverty. In this estimate, the author finds that there is a strong relationship between poverty capabilities and economic well-being.

Di Tommaso [41] uses the CA to suggest a model for estimating the welfare of Indian children. From the following capabilities: body health, sense of imagination and thinking and leisure activity and play, she estimates the welfare of children, considered as a latent variable, through the MIMIC model. Also, in this context, according to one of the main conclusions of the study; there would be a strong relationship between the capabilities of children and their levels of wellbeing.

With the same target population [42] applying an SEM-CB of the Bolivian data from 2002 to estimate two capabilities of children aged 7 - 14 years: knowledge (ability to be educated) and living conditions (ability to be housed properly). These capabilities and their indicators are chosen according to the availability of data in the base of MECOVI Bolivian program. The result of their estimation with SEM shows a strong interdependence between capabilities and a major impact on factors such as ethnicity, family, and infrastructure in the well-being.

In the Pakistani context, [43] describes a model that simultaneously considers the capabilities, the functioning and conversion factors. This model is estimated with the Pakistani investigation data PSES (Pakistant Socio-economic Survey), conducted in 1998. In this dataset, the author uses the answers to the questions: "Is your life interesting? And have you been able to enjoy the day to day of your activities?" With the PLS-PM Technical, he finds that capabilities are positively related to functioning and freedoms. Hassan [44] uses the same dataset and shows with two estimation techniques: SEM and MCO that capabilities are most important and stable determinants of subjective well-being.

Anand, et al. [34] examined the relationship that exists between capabilities and happiness and, given the heterogeneity between individuals. With a sample of 976 adults, they seek with the SEM to model the direct effects of capabilities on the satisfaction of general life, taking into account heterogeneities related to personal traits of individuals who act on reported life satisfaction and achievement of capabilities. The SEM estimations show that happiness depends on the capabilities, autonomy and social life.

In an Ethiopian context, [45] operationalize Sen's approach in assessing the relationship between capabilities and functioning "be happy" or subjective wellbeing of women rural Ethiopians. The capabilities are selected according to the data available in the dataset EHRS (Ethiopian Household Rural Survey). With the use of the SEM, especially MIMIC, it gives the result: the existence of a strong correlation between the capabilities (perception of agency and salary) and achievement of subjective well-being: "be happy".

Thus, the use of SEM is in early stage in the empirical literature of the CA,

$\overline{{ }^{1} \text { Structural equation modeling covariance based. }}$. 
which means that it is relatively limited. It is in this sense also that this article seeks to explore the context of Senegal, where there is not, to our knowledge, a study that attempted to measure the capabilities as framework for well-being measurement. Also, this paper is the first to use SEM approach in measurement well-being in Senegal and, particularly, PLS-PM (Partial Least Square-Path Modeling) in CA, excepted Hassan [43].

\section{Methodology}

\subsection{Choice of Dimensions}

In the evaluation process, the choice of dimensions and indicators is seminal. According to [46], the choice of the first is based on theoretical foundations or philosophical view and the later on practical or statistical considerations. Regarding the choice of dimensions, there is no list of predefined capabilities in Sen, unlike Nussbaum [47] offering. Sen [48] argues that any list should be specific to the study contexts and determine by a public reasoning. According to [49], there are five methods generally used by applications of CA and multidimensional poverty, to select the relevant dimensions and that is: the fact of being based on existing data; to make normative assumptions based on the values of the society that uphold social or religious theories; using a set of dimensions that result from a consensus or public discussion, as the Millennium Development Goals, the human rights...; to initiate a deliberative participation and to base on empirical evidence.

In this paper, we rely on the theory including that of Sen and Nussbaum choose values dimensions. In fact, in an assessment context as that of the country in development, we choose the basic capabilities [50], which are: the freedom to enjoy good living conditions, freedom to read and write freedom to lead a life free from disease, freedom to eat properly and freedom to participate in public and social life of the community. These dimensions refer to all of the items prioritized by Senegalese for human development in the "My World" survey [51]. Next, we take a broader definition of health that includes nutrition, which is the bodily health. Moreover capabilities "participations in public and social life" is divided into two distinct dimensions are: good governance and social ties (not institutional support). The first is the fifth priority according to the results of My World. As for the second, we consider its relevance following the socio-cultural context of the country and we propose to test its relevance in measuring well-being.

Furthermore, beside its basical capabilities, we conceptualize well-being in three dimensions. First, there is the economic well-being is measured in terms of assessment of the level of wealth, economic status or income. So instead of taking the income as a resource, we use the perception of the economic situation that can in some sense be regarded as a capability referring to "control his material environment" as defined by [2], in its central capabilities list. Secondly, we have the satisfaction of life and subjective well-being as dimensions of happiness. With [5], we have a definition of happiness as a capability and can serve as a control element in the achievement of other capabilities. 
Consequently, we have the following dimensions: living conditions, education, body health, social ties (not institutional support), good governance, economic well-being, life satisfaction and subjective well-being. At each of its dimensions will match one or more indicators that are considered in the CA as accomplishments or functionings. As we mentioned above, the choice of these indicators will depend on the availability of data in the dataset as an information source mobilized.

\subsection{Structural Equation Model to PLS-PM}

The challenges of operationalizing the CA require specific statistical techniques to take into account the multidimensional nature of the approach and the interactions between its variables. Moreover, in addition to the fuzzy set theory (FST), the multivariate data reduction techniques and regression approaches, SEM is a relevant new tool for empirical modeling of CA [52]. It's statistical tool for modeling causal relationships between multiple variables defined from a theoretical model. Thus, the SEM has for innovative idea-which makes them the second of generational patterns being able to estimate the complexity, by taking into account the system of a causal relationship between a latent concept and several observed variables, say manifest variables [53]. There are two types of models in the SEM: the measurement model (or external model) and the structural model (or internal model). In addition, there are two types for SEM modeling: the hard modeling and the soft one. The first is the so-called LISREL (Linear Structural Relation). It is based on the analysis of covariance matrix. LISREL is a method that is quite complex, based on the CPA and confirmatory factor analysis, it is unusual to require rather restrictive assumption as the normal distribution of data, identification of models, etc. This is why it is referred to as a rough method. Note also that this is a confirmatory method, therefore, requires an existing theory that we must confirm or compared to data available to the researcher. Conversely, the PLS-PM method is called soft because it requires few assumptions and its implementation is relatively convenient. This approach based on estimates partial least squares and was developed by [54] [55]. In contrast, the LISREL approach, the PLS is predictive approach and ranks among the most exploratory methods. Indeed, it does not require an existing theory and could be a first step before modeling approach of covariance calling LISREL (Linear Structural Relation).

For now, the method of structural equations prevailing in the well-being measurement literature and in the empirical literature of the CA is the LISREL approach (SEM-ML) [40] [41] [42]. We have not to our knowledge another application of PLS-PM in the empirical literature CA outside Hassan [43]. However, regarding the CA we believe with [43] that modeling by the PLS-PM is relevant for the simple reason that the $\mathrm{CA}$ is an approach, not a theory, and that relations between capabilities must be modelled according to the context and purposes of the study. Furthermore, given the theoretical complexity of the CA and that Sen strongly advocates a sensitivity of evaluation in context, the PLS approach would be more appropriate than confirmatory: SEM-ML. 


\section{Application: Evaluation of a Structural Model of Welfare in Senegal}

\subsection{Model Specification}

Specifying the model consists of the MES to set the measurement and structural models. The first describes the relationship between manifest variables and latent variables; and the second consists of all relationships between the latent variables between them. We build an outer model that is reflective type, i.e. the manifest variables are the reflections of their latent variables.

$$
x_{h}=\pi_{h 0}+\pi_{h} \xi+\varepsilon_{h}
$$

where $x_{h}$ is vector of manifest variables (functioning) of latent variable (capabilities and well-being); $\pi_{h}$ is the loading associated to manifest variables $x_{h}$ and $\varepsilon_{h}$ the error term represents the imprecision in the measurement process.

The indicators are chosen from the ESPS-II (Enquête de suivi de la pauvreté au Sénégal) dataset. Table $1 \mathrm{~A}$ in the Appendix gives the indicators for each dimension associated with it and its terms. For inner or structural model, the relationship between latent variables is assumptions that the estimate should confirm or deny. Trivially, we assume that capabilities affect the dimensions of wellbeing (economic, life satisfaction and subjective well-being). Relations between the dimensions are derived from the empirical literature of the CA and the application context.

Figure 1 below shows the model shows that each of his supposed relationship.

$$
\xi_{j}=\beta_{j 0}+\sum_{i} \beta_{j i} \xi_{i}+v_{j}
$$

where $\xi_{j}$ as endogen latent variable and $\xi_{i}$, the $i$-th exogenous latent variables or independent of inner model; $\beta_{j 0}$ is the intercept and $\beta_{j i}$ is the generic path coefficient interrelating the $i$-th exogenous latent variable to the $j$-th one, $v_{j}$ is the error in the inner relation (i.e. disturbance term in the prediction of the $j$-th endogenous laten variable from its explanatory latent variables).

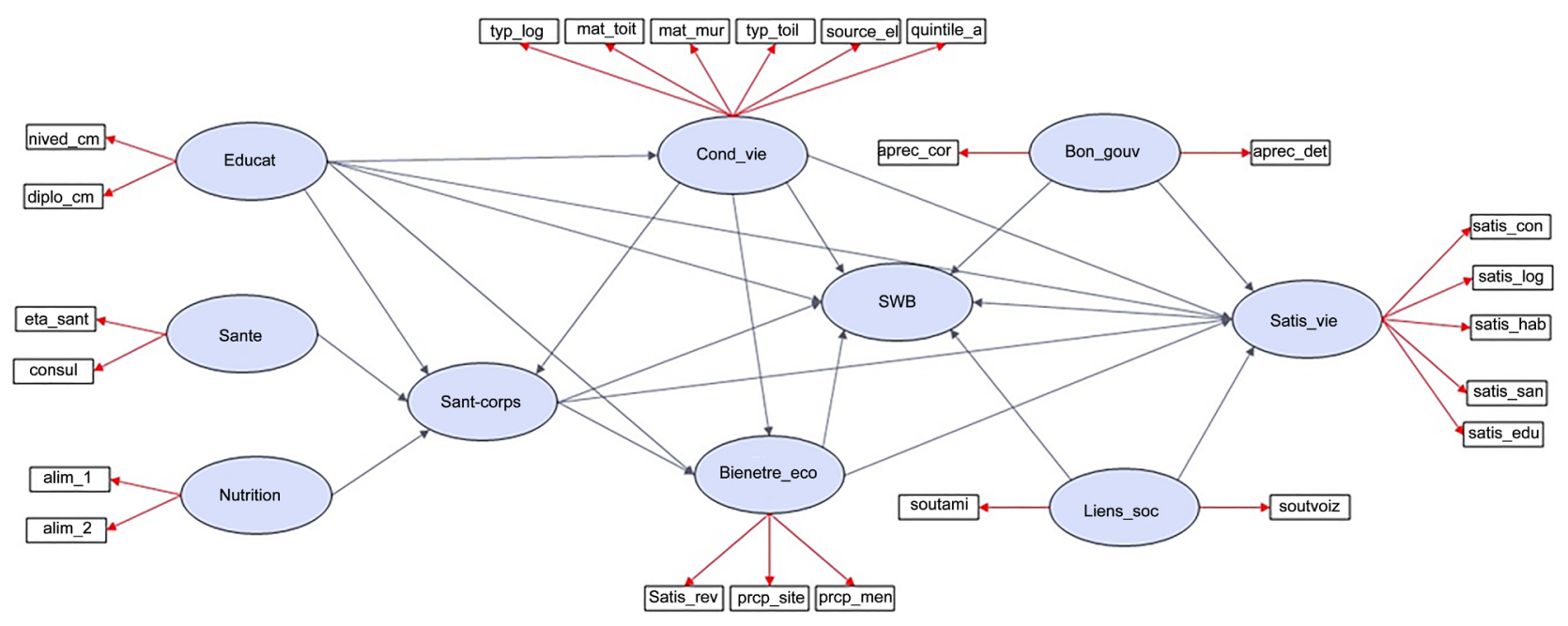

Figure 1. The basic model. Source: Authors with XLSTAT-PLSPM. 
The model to estimate is presented in the following figure.

\subsection{Source of Information}

In 2011, the State of Senegal through its National Agency of Statistics and Demography (ANSD) launched a follow-up survey of poverty: follow-up survey of poverty in Senegal (ESPS-II), second of its kind after the ESPS-I. This one gave aim to collect information on the main indicators of poverty, develop a profile of poverty, highlight the socioeconomic characteristics of different social groups and ultimately to analyze the determinants of poverty [56]. 20250 on sample households, 17891 were eventually interviewed. However, ANSD in its final report notes that the household sample was divided into two groups, one called sub-sample that received the total administration of the household questionnaire; while the other portion of households forming the expanded sub-sample had a lighter application of this questionnaire [56]. In doing so, the 17891 households surveyed are distributed as follows: 5953 households received the questionnaire in its entirety and 11938 households was applied partial questionnaire. Our work covers the reduced sample subsample of ESPS-II. Some variables such as subjective well-being or, more broadly, those that are part of Section $\mathrm{L}$ are available for individuals of partial subsample. By giving us [56], we believe this fairly representative sample size that we will base our empirical work. By construction, we exclude from this sample household heads who are not Senegalese nationalities and for which we have a high rate of non-response in relation to certain issues. So we spend a sample of 5953 to 5873 individuals.

\subsection{Estimation and Results}

The XLSTAT software that has a module XLSTAT-PLSPM mobilized to estimate model presented in Figure 1. For the regression, we use the partial least square method (PLS) instead of OLS end to guard against the risk of co-linearity as recommended by Tenenhaus et al. [57]. In addition, for purposes of prediction and not evaluation, regression by partial least squares is indicated.

Figure 2 shows the results of the model with the structural factors and manifest variables communities. In the SEM in general, PLS-PM in particular, the results of the model analysis on three levels: outer model, inner model and global model.

\subsubsection{Outer Model}

Our model is hierarchical component model (HCM) type, i.e. we have a latent variable, which has the obvious indicators of others latent variables. These are the: bodily health. Thus, to evaluate the results of the measurement model, according to [58], we will test the reliability and internal consistency and validity to the dimensions of the first order. As for the hierarchy variable, the reliability is not relevant for these types of variables [59]; only the criterion of validity will be tested. Table 1 summarizes the different criteria for accepting the validity of the measurement model.

So our outer model respects the internal consistency criteria with a Rho Dillon 


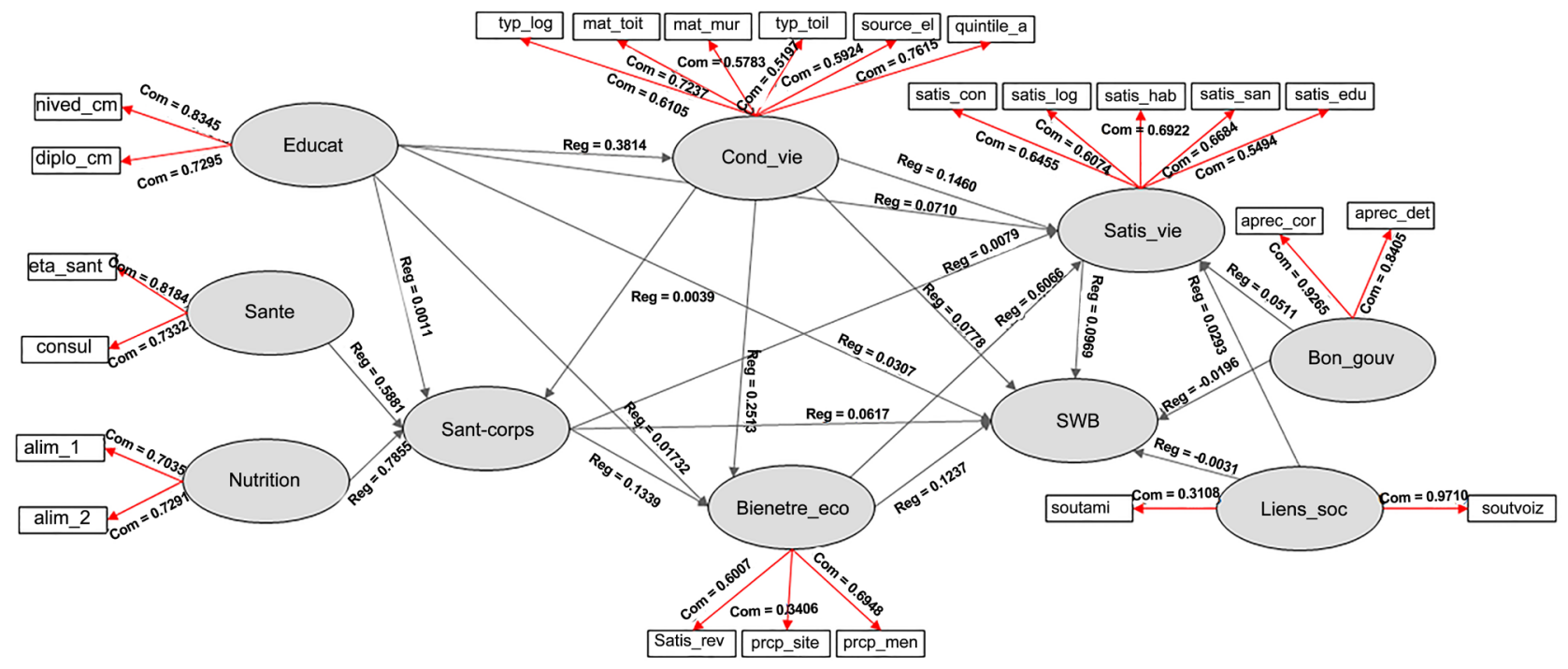

Figure 2. Basic model estimated. Source: Authors, from XLSTAT-PLSPM.

Table 1. Criteria for accepting the validity of the measurement model.

\begin{tabular}{|c|c|c|c|}
\hline Validity Type & Criterion & Description & Literature \\
\hline Unidimensionality & $\begin{array}{l}\text { Exploratory } \\
\text { Factor Analysis } \\
\text { (EFA) }\end{array}$ & $\begin{array}{l}\text { The number of selected factors is } \\
\text { determined by the numbers of } \\
\text { factors with an eigenvalue greater } \\
\text { than 1.0. }\end{array}$ & $\begin{array}{c}\text { Gerbing and } \\
\text { Anderson } \\
{[60]}\end{array}$ \\
\hline $\begin{array}{l}\text { Internal } \\
\text { Consistency } \\
\text { Reliability }\end{array}$ & Cronbach Alpha & $\begin{array}{l}\text { Should be greater than } 0.70 \text { to } \\
\text { achieve the reliable of measure- } \\
\text { ment model. }\end{array}$ & $\begin{array}{l}\text { Nunnally } \\
{[61]}\end{array}$ \\
\hline $\begin{array}{l}\text { Internal } \\
\text { Consistency } \\
\text { Reliability }\end{array}$ & $\begin{array}{l}\text { Composite } \\
\text { Reliability }\end{array}$ & $\begin{array}{l}\text { Alternative to Cronbach Alpha } \\
\text { that attempt to measure the sum of } \\
\text { an LV's factor loadings relative to } \\
\text { the sum of the factor loadings plus } \\
\text { error variances. }\end{array}$ & $\begin{array}{c}\text { Nunnally and } \\
\text { Bernstein } \\
{[62]}\end{array}$ \\
\hline $\begin{array}{l}\text { Indicator } \\
\text { Reliability }\end{array}$ & $\begin{array}{l}\text { Indicator } \\
\text { Loadings }\end{array}$ & $\begin{array}{l}\text { Measures how much of the } \\
\text { indicators variance is explained by } \\
\text { the coresponding latent variables. }\end{array}$ & Chin [63] \\
\hline $\begin{array}{l}\text { Convergent } \\
\text { Validity }\end{array}$ & $\begin{array}{l}\text { Average Variance } \\
\text { Extracted (AVE) }\end{array}$ & $\begin{array}{l}\text { Proposed threshold value for AVE } \\
\text { should be higher than } 0.50 \text {. }\end{array}$ & $\begin{array}{l}\text { Fornell and } \\
\text { Larcker [64] }\end{array}$ \\
\hline $\begin{array}{l}\text { Discriminant } \\
\text { Validity }\end{array}$ & $\begin{array}{l}\text { Fornell-Larcker } \\
\text { criterion }\end{array}$ & $\begin{array}{l}\text { The AVE of each latent variable } \\
\text { should be greater than the latent } \\
\text { variable highest squared correla- } \\
\text { tion with any other latent variable. }\end{array}$ & $\begin{array}{l}\text { Fornell and } \\
\text { Larcker [64] }\end{array}$ \\
\hline
\end{tabular}

Source: Extract from Afthonaran's paper [65].

Goldstein varying between 0.7886 (for the variable representing Economic Well-being) to 0.9402 (Good governance). According to [60], the Rho Dillon Goldstein is more reliable than the Cronbach alpha. The issue of internal consistency and multidimensionality is not an issue for single-item latent variables, as 
in our model with the latent variable "SWB". For reliability indicators which refers to their ability to be explained by their latent variables, loadings indicators are higher than 0.7 .

This implies communalities that are above 0.5 (Table $2 \mathrm{~A}$ attached). Only the manifest variables "soutami" and "prcp_sitmen" have communalities that are less than 0.5:0.31 and 0.34 respectively. But they belong to other dimensions where components have communalities that are high. So in general, we can accept the reliability of our indicators.

After testing the reliability of indicators and their latent constructs, the next step in the validation of the outer model includes a review of the validity of built. Within the HCM, [58] states that the validity of the measurement model is tested on two levels: the first order and second order. For models of first order must test the existence of a convergent validity and discriminant validity. Validation of the second order must obey following [58] and [66], when it is Type-II, the same requirements as those required with a formative model. According to [59] and [67], built the second order must consist of sub dimensions that meet the criteria of validity of formative indicators given by calculating the collinearity test what the VIF (Variance Inflation Factor) which is the reverse tolerance and which measures the amount of variance explained by other influences. According to the literature, the value of VIF must be greater than 0.2 , but less than 5 [68] [69].

Table 2A in Annex shows that the AVE of all latent variables first order satisfies the convergent validity and criterion Fornell and Larcker. The variable "Bien-etre_eco" is one that has the smallest AVE of the first order, i.e.: 0.5453. For the variable "Sant-corps" the AVE calculated is beyond consideration of this criterion validity, as being a latent variable of the second type-II order is a formative built the two first-order variables. For discriminant validity, Table 3A (attached) shows that all variables meet the criterion of discriminant validity. Indeed, the squares of correlations of each of these variables and other variables are below their AVE.

Regarding construct validity of the second order, the VIF calculated for the two sub-dimensions are all less than 2 (Table $4 \mathrm{~A}$ ). Thereby, we accepted the validity of the first order that is constructed the "Health" and "Nutrition" on the second order. In short, the external model that meets the tests of validity and reliability, we can infer that the indicators chosen are well built. That said, we can present the results of the internal model and examine its validity in the light of the criteria defined in the literature of the PLS approach.

\subsubsection{Inner Model}

The result presentation of inner model is based on an analysis of the predictive quality of the model and the structural significance of path regression that can confirm or refute the assumptions of this model. The predictive quality is given by the analysis of $R^{2}$ or $R^{2}$ adjusted. However, $Q^{2}$ Stone-Geisser [60] [70] [71] [72] is presented as being better for the assessment of the predictive quality.

The formula of $Q^{2}$ Stone-Geisser is given as: 


$$
Q_{j}^{2}=1-\frac{\sum_{k} E_{j k}}{\sum_{k} O_{j k}}
$$

with $E_{j k}$ as the square of the predictor errors; $O_{j k}$ squared predictor error trivial given by the average of the remaining data of the procedure Blindfolding; $j$ observed endogenous measures and $k$ indices all indicators of the measurement model. If the value of $Q^{2}$ Stone-Geisseris greater than 0 , the model has good predictive validity. Otherwise, it will be irrelevant [60]-[72].

The structural regression coefficients are estimated and their significance test is obtained from the method of resampling bootstrap (or Jackknife), as the $R^{2}$. Therefore, we will analyze each structural equation of the inner model, which are five in number (the number of endogenous latent variables). All results are summarized in Table 2.

The variable "Cond_vie" is explained in our model by the single latent variable representing education. The regression coefficient is significantly positive, or 0,3814 . An average redundancy of 0.0935 indicates that the variable "Educat" predicts less than $10 \%$ of the variations in the average manifest variables of block? "Cond_vie" (Table 3).

Table 2. Path coefficients of inner model.

\begin{tabular}{|c|c|c|c|c|c|}
\hline $\begin{array}{c}\text { Variables } \\
\text { dépendantes }\end{array}$ & $\begin{array}{c}\text { Independant } \\
\text { Variables }\end{array}$ & $\begin{array}{c}\text { Path Coeffi- } \\
\text { cients } \\
\text { Values }\end{array}$ & $\begin{array}{c}\text { Value } \\
\text { (Bootstrap) }\end{array}$ & $\begin{array}{c}\text { Standard } \\
\text { Error } \\
\text { (Bootstrap) }\end{array}$ & $\begin{array}{c}\text { Critical } \\
\text { Ratio } \\
(\mathrm{CR})\end{array}$ \\
\hline Con_vie & Educat & $0.3814^{\star * *}$ & 0.3805 & 0.0091 & 41.9599 \\
\hline \multirow{4}{*}{ Sant-corps } & Educat & 0.0011 & 0.0013 & 0.0009 & 1.3395 \\
\hline & Sante & $0.58818^{* * *}$ & 0.5910 & 0.0154 & 38.2052 \\
\hline & Nutrition & $0.7855^{\star * *}$ & 0.7824 & 0.0132 & 59.3218 \\
\hline & Cond_vie & $0.0039^{*}$ & 0.0039 & 0.0009 & 4.2114 \\
\hline \multirow{3}{*}{ Bien-etre_eco } & Educat & $0.1732^{\star * *}$ & 0.1727 & 0.0083 & 20.7482 \\
\hline & Cond_vie & $0.2513^{* * *}$ & 0.2519 & 0.0081 & 31.2058 \\
\hline & Sant-corps & $0.1339^{* * *}$ & 0.1324 & 0.0083 & 16.1595 \\
\hline \multirow{6}{*}{ Satis_vie } & Educat & $0.0710^{* *}$ & 0.0707 & 0.0132 & 5.3846 \\
\hline & Cond_vie & $0.1460^{* * *}$ & 0.1467 & 0.0095 & 15.3619 \\
\hline & Sant-corps & 0.0079 & 0.0057 & 0.0098 & 0.8088 \\
\hline & Bien-etre_eco & $0.6066^{* * *}$ & 0.6071 & 0.0083 & 73.0833 \\
\hline & Bon_gouv & $0.0511^{*}$ & 0.0500 & 0.0109 & 4.7103 \\
\hline & Liens_soc & -0.0293 & -0.0288 & 0.0112 & -2.6129 \\
\hline \multirow{7}{*}{ SWB } & Educat & $0.0307^{\star *}$ & 0.0308 & 0.0053 & 5.8201 \\
\hline & Cond_vie & $0.0778^{\star \star *}$ & 0.0784 & 0.0048 & 16.0659 \\
\hline & Sant-corps & $0.0617^{\star *}$ & 0.0606 & 0.0078 & 7.9313 \\
\hline & Bien-etre_eco & $0.1237^{\star * *}$ & 0.1236 & 0.0052 & 23.5784 \\
\hline & Bon_gouv & -0.0196 & -0.0195 & 0.0065 & -3.0372 \\
\hline & Liens_soc & 0.0031 & 0.0047 & 0.0060 & 0.5188 \\
\hline & Satis_vie & $0.0969^{* * *}$ & 0.0972 & 0.0041 & 23.9233 \\
\hline
\end{tabular}

Notes: Critical Ratio (CR) for define the significativity. ${ }^{*} \mathrm{CR}$-Value higher than 2 ; ${ }^{* *} \mathrm{CR}-$ Value higher than 5 ; ${ }^{* *} \mathrm{CR}$ value higher than 10 . Source: Author, with XLSTAT-PLSPM. 
The variable "Sant-corps" is a construct of the second order formed by the first order latent variables that are "Sante" and "Nutrition" and caused by "Educat" and "Cond_vie". The path coefficients obtained from the PLS regression indicate the existence of a positive causal relationship of these variables on the "Sant-corps" but only causality of the living conditions on the body's health is significant, with a coefficient of 0.004 (Table 2). With regard to the predictability of this latent variable, it has a 0.3836 redundancy index. Reflecting the fact that the variables: Health, Nutrition, and Educat Cond_vie predict on average $38 \%$ of the variance in indicators of health of the body. In sum, the predictive quality of this variable is provided with a positive $Q^{2} 0.9841$.

The variable "Bien-etre_eco" is determined by the variables: Cond_vie, Educat and Sant-corp. All three variables have coefficients that are all positive and significant. Regarding the prediction, redundancy is 0.0834 . It reflects, in this sense, an ability to predict the manifest variables of economic well-being by the three built which is relatively low. However, with $Q^{2}$ non-zero $(0.1521)$, there has to be concluded in favor of predictive validity exogenous dimensions of economic well-being.

Life satisfaction is explained by all latent variables, except that relating to the subjective well-being. The coefficients are all positive, as we had assumed in the specification of the inner model, except the non-institutional support. The latter, as well as the health of the body are the only ones not to be significant at the $5 \%$ level. The independent variables predict on average $30 \%(0.3042)$ of the average variance of the indicators of life satisfaction; and the predictive quality of the model according to Statistics $Q^{2}$ Stone-Geisser is relevant to the extent that the value taken by this indicator is above zero, i.e.: 0.4242 .

Subjective well-being (SWB) is influenced by all dimensions. All path coefficients, with the exception of those relating to good governance and non-institutional support, are significantly positive. Thus, all the basic capabilities

Table 3. Predictive quality of inner model.

\begin{tabular}{|c|c|c|c|c|c|c|}
\hline Latent Variable & Type & $\mathrm{R}^{2}$ & $\begin{array}{c}\mathrm{R}^{2} \\
\text { adjusted }\end{array}$ & AVE & $\begin{array}{c}\text { Average } \\
\text { Redondancy }\end{array}$ & $Q^{2}$ Stone-Geisser \\
\hline Educat & Exogenous & & & 0.782 & & \\
\hline Sante & Exogenous & & & 0.7758 & & \\
\hline Nutrition & Exogenous & & & 0.7163 & & \\
\hline Cond_vie & Endogenous & 0.1455 & 0.1455 & 0.643 & 0.0935 & \\
\hline Sant-corps & Endogenous & 0.9984 & 0.9984 & 0.3812 & 0.3806 & 0.9841 \\
\hline Bien-etre_eco & Endogenous & 0.1529 & 0.1526 & 0.5453 & 0.0834 & 0.1521 \\
\hline Bon_gouv & Exogenous & & & 0.8835 & & \\
\hline Liens_soc & Exogenous & & & 0.6409 & & \\
\hline Satis_vie & Endogenous & 0.4809 & 0.4804 & 0.6326 & 0.3042 & 0.4242 \\
\hline SWB & Endogenous & 0.0756 & 0.0746 & 1 & 0.0756 & 0.0723 \\
\hline Average & & 0.3706 & & 0.635 & 0.1874 & \\
\hline
\end{tabular}

Source: Authors, with XLSTAT-PLSPM. 
(education, living conditions and bodily health), economic well-being and life satisfaction positively cause the feeling of being happy. Furthermore, the predictive power of the model shows that independent variables provide, generally, a relevant predictive quality model with $Q^{2}$ Stone-Geisser which is significant, is not zero and is positive: 0.0723 (see Table 3 ). In sum, the predictive quality of the model, it is quite acceptable. Indeed, we have an average of 0.1874 redundancy model. Given the subjective nature of the data, we have an average forecast of manifest variables with the latent variables of $19 \%$.

\subsubsection{Global Model}

The GoF implemented by [73] is retained in the literature as an indicator for assessing the fit quality of the model. It is the product of the AVE and R2. Our model has a GoF 0.4851. The value of the GoF is greater than 0.36 , which is the threshold, used by [74] to assert for the good predictive quality. As for the relative GoF, it is 0.8964 and rounded to the nearest tenth is equal to 0.900 is the threshold defined by [53] to judge the good quality of the model. The values of the internal and external GoF which are 0.9915 and 0.9041 respectively are also significant. From these results we can say that our model with good predictive quality overall.

\section{Discussion and Conclusion}

In the context of Senegal, our results do not show a large difference with those that we find in the theoretical and empirical literature of the CA. In this sense, the basic capabilities as education are significant for all other dimensions, except for the bodily health. This result shows the centrality of this capability as for Nussbaum and Sen Theory. The capability living conditions which bring together, in our definition, all basic functionings "be well housed" (sanitation, comfort...) are the most stable determining of all well-being dimensions and the capability: bodily health.

So even if our results show that bodily health, surprisingly, does not significantly determine life satisfaction, it is causal subjective and economic well-being. From this, our model gives results that are in line with [40] [42] [43] and [34] [44] or [45]. There is, in this sense, a confirmation of the thesis of [5] on "proof by happiness." In addition, the importance of economic well-being (or the perception of the economic situation) in the explanation of life satisfaction and subjective well-being lead us to suspect a determining role of income in happiness. Subjective well-being depends more on the satisfaction for financial position and satisfaction of life. In order, the capability living conditions are the most important in the determination of subjective well-being; it is followed by the body's health and education.

Finally, social ties measured as non-institutional support, are not significant in the determination of life satisfaction or subjective well-being. The explanation that we find is that the non-institutional support refers to a state of lack of autonomy. Indeed, it is those who do not have the living conditions or other minimum accomplishments that are supported by their neighbors or friends. This 
support can be seen as a situation of dependency and does not affect the wellbeing as is the case with life satisfaction (see Table 2). Also, good governance, as measured by the perception of the evolution of corruption and diversion, has a significant effect only on life satisfaction. She did not significantly influence the feeling of being happy. Ultimately, our objective was to propose a structural model to conceptualize well-being highlighting all relationships between these different dimensions. The use of latent variable model enabled us to quantify capabilities and examine the causal relationships which they had on each other. Our results argue in favor of CA and its relevance in a multidimensional measuring of well-being. However, our model suffers from a limit and that is the lack of consideration of cultural and individual social factors, like age, background and gender. Thus, in a research perspective, we use multi-group analysis or the moderating effects of the PLS-PM to study the effect of these factors. The use of a MIMIC model in a confirmatory framework is also a relevant research track to achieve this purpose.

\section{References}

[1] Sen, A.K. (1983) Poor, Relatively Speaking. Oxford Economic Papers, 35, 153-169.

[2] Nussbaum, M. (2012) Capabilités: Comment créer les conditions d'un monde plus juste? Flammarion, Paris.

[3] Sen, A.K. (1980) Equality of What? In: McMurrin, S.M., Ed., Tanner Lectures on Human Values, Vol. 1, Cambridge University Press, Cambridge.

[4] Sen, A.K. (1992) Inequality Reexamined. Clarendon Press, Oxford.

[5] Sen, A.K. (2012) L'idée de justice. 2nd Edition, Flammarion, Paris.

[6] Robeyns, I. (2005) The Capability Approach: A Theoretical Survey. Journal of Human Development, 6, 93-117. https://doi.org/10.1080/146498805200034266

[7] Qizilbash, M. (2008) Amartya Sen's Capability View Insightful Sketch or Distorted Picture? In: Alkire, S., Qizilbash, M. and Comim, F., Eds., The Capability Approach: Concepts, Measures and Applications, Cambridge University Press, Cambridge and New York.

[8] Robeyns, I. (2006) The Capability Approach in Practice. Journal of Political Philosophy, 14, 351-376. https://doi.org/10.1111/j.1467-9760.2006.00263.x

[9] Alkire, S. (2005) Valuing Freedoms: Sen's Capability Approach and Poverty Reduction. 1st Edition, Oxford University Press, Oxford.

[10] Sen, A.K. (2000) Repenser l'inégalité. Seuil, Paris.

[11] Sugden, R. (1993) Welfare, Resources, and Capabilities: A Review of Inequality Reexamined by Amartya Sen. Journal of Economic literature, 31, 1947-1962.

[12] Ysander, B.C. (1993) Comment to Erikson's Work "Description of Inequality": The Swedish Approach to Welfare Research. In: Nussbaum, M. and Sen, A., Eds., Quality of Life, Clarendon Press, Oxford, 84-88.

[13] Srinivasan, T.N. (1994) Human Development: A New Paradigm or Reinvention of the Wheel? The American Economic Review, 84, 238-243.

[14] Roemer, J.E. (1996) Theories of Distributive Justice. Harvard University Press, Cambridge.

[15] Rawls, J. (1999) The Law of Peoples: With, the Idea of Public Reason Revisited. Harvard University Press, Cambridge. 
[16] Ndiaye, B. (2005) Les déterminants de la pauvreté rurale au Sénégal. IDEP, Bali.

[17] Cisse, F. (1997) La pauvreté rurale au Sénégal: Profil et déterminants. Mémoire de DEA, FASEG, UCAD, Dakar.

[18] Cisse, F. (2003) Le profil de Pauvreté au Sénégal: Une analyse de la robustesse des comparaisons de pauvreté. MIMAP, Rapport de recherche.

[19] Cisse, F. (2003) Le profil de la pauvreté au Sénégal: Une approche monétaire. MIMAP, Rapport de recherche.

[20] Badji, M.S. and Boccanfuso, D. (2006) La tendance d'évolution de la pauvreté féminine et de ses déterminants: Le cas des ménages conduits par des femmes au Sénégal. Cahier de recherche/Working Paper, 6.

[21] Ki, J., Faye, B. and Faye, S. (2002) Pauvreté multidimensionnelle au Sénégal: Approches non monétaires fondées sur les besoins fondamentaux. CREA-Sénégal.

[22] Ki, J., Faye, S. and Faye, B. (2005) Multidimensional Poverty in Senegal : A NonMonetary Basic Needs Approach. Cahiers de recherche PMMA. No. 2005-05.

[23] Boccanfuso, D., Esatche, A. and Savard, L. (2009) A Macro-Micro Analysis of the Effects on Electricity Reform in Senegal on Poverty and Distribution. Journal of Development Studies, 45, 351-368. https://doi.org/10.1080/00220380802582361

[24] Mussard, S. and Pi Alperin, M.N. (2005) Théorie des ensembles flous et décomposition multidimensionnelle de la pauvreté: Le cas du Sénégal. GREDI, Groupe de Recherche en Economie et Développement International.

[25] Diallo, F.L. and Hamani, O. (2010) Tendance de la pauvreté au Sénégal entre 1994 et 2001: Une approche multidimensionnelle basée sur les ensembles flous. Consortium pour la recherche économique et sociale (CRES) MIMAP/ Sénégal, No. 2010/21.

[26] Diop, M. (2014) L'approche par les capabilités comme instrument d'analyse de la pauvreté: Une application sur des données du Sénégal. Innovations sociales, innovations économiques, Presses universitaires de Louvain, 179-201.

[27] Sen, A.K. (1987) On Ethics and Economics. Blackwell, Oxford.

[28] UNDP (1990) Human Development Report 1990. United Nations Development Programme (UNDP).

[29] Schokkaert, E. and Van Ootegem, L. (1990) Sen's Concept of the Living Standard Applied to the Belgian Unemployed. Recherches Économiques de Louvain/Louvain Economic Review, 56, 429-450.

[30] Brandolini, A. and D'Alessio, G. (1998) Measuring Well-Being in the Functioning Space. General Conference of the International Association for Research in Income and Wealth, Cambridge, 23-29 August 1998.

[31] Chiappero, M.E. (2000) A Multidimensional Assessment of Well-Being Based on Sen's Functioning Approach. Rivista Internazionale di Scienze Sociali, 108, 207-239.

[32] Anand, P. and VanHees, M. (2006) Capabilities and Achievements: An Empirical Study. The Journal of Socio-Economics, 35, 268-284. https://doi.org/10.1016/j.socec.2005.11.003

[33] Krishnakumar, J. (2007) Going beyond Functionings to Capabilities: An Econometric Model to Explain and Estimate Capabilities. Journal of Human Development, 8, 39-63. https://doi.org/10.1080/14649880601101408

[34] Anand, P., Krishnakumar, J. and Tran, N.B. (2011) Measuring Welfare: Latent Variable Models for Happiness and Capabilities in the Presence of Unobservable Heterogeneity. Journal of Public Economics, 95, 205-215.

https://doi.org/10.1016/j.jpubeco.2010.11.007 
[35] Klasen, S. (2000) Measuring Poverty and Deprivation in South Africa. Review of Income and Wealth, 46, 33-58. https://doi.org/10.1111/j.1475-4991.2000.tb00390.x

[36] Qizilbash, M. (2002) A Note on the Measurement of Poverty and Vulnerability in the South African Context. Journal of International Development, 14, 757-772. https://doi.org/10.1002/jid.922

[37] Qizilbash, M. and Clark, D.A. (2005) The Capability Approach and Fuzzy Poverty Measures: An Application to the South African Context. Social Indicators Research, 74, 103-139. https://doi.org/10.1007/s11205-005-6527-y

[38] Temitayo, A.A. and Omobowale, O.A. (2013) A Functioning Approach to Well Being Analysis in Rural Nigeria. Sustainable Agriculture Research, 2, 149-163.

[39] Kuklys, W. (2005) Amartya Sen's Capability Approach: Theoretical Insights and Empirical Applications. Springer Science \& Business Media, Berlin.

[40] Wagle, U. (2005) Multidimensional Poverty Measurement with Economic WellBeing, Capability, and Social Inclusion: A Case from Kathmandu, Nepal. Journal of Human Development, 6, 301-328. https://doi.org/10.1080/14649880500287621

[41] Di Tommaso, M.L. (2007) Children Capabilities: A Structural Equation Model for India. The Journal of Socio-Economics, 36, 436-450. https://doi.org/10.1016/j.socec.2006.12.006

[42] Krishnakumar, J. and Ballon, P. (2008) Estimating Basic Capabilities: A Structural Equation Model Applied to Bolivia. World Development, 36, 992-1010. https://doi.org/10.1016/j.worlddev.2007.10.006

[43] Hassan, H. (2009) Capabilities Measurement: An Empirical Investigation. MPRA Paper, No. 16742.

[44] Hassan, H. (2013) Capabilities vis-à-vis Happiness: Evidence from Pakistan. MPRA Paper, No. 44892.

[45] Mabsout, R. (2011) The Capability Approach: From Ethical Foundations to Empirical Operationalization. PhD Thesis, Erasmus University, Rotterdam.

[46] Krishnakumar, J. (2014) Quantitative Methods for the Capability Approach. In: Encyclopedia of Life Support Systems (EOLSS) Developed under the Auspices of the UNESCO, Ed., Social and Cultural Development of Human Resources, Eolss, Publishers, Paris, 1-30.

[47] Nussbaum, M.C. (2000) Women and Human Development: The Capabilities Approach. Cambridge University Press, Cambridge. https://doi.org/10.1017/CBO9780511841286

[48] Sen, A.K. (2004) Capabilities, Lists, and Public Reason: Continuing the Conversation. Feminist Economics, 10, 77-80. https://doi.org/10.1080/1354570042000315163

[49] Alkire, S. (2007) Choosing Dimensions: The Capability Approach and Multidimensional Poverty. In: Kakwani, N. and Silber, J., Eds., The Many Dimensions of Poverty, Palgrave Macmillan, New York, 89-119. https://doi.org/10.1057/9780230592407_6

[50] Sen, A.K. (1985) Commodities and Capabilities. North-Holland, Amsterdam.

[51] Direction Générale du Plan (DGP) (2013) Enquete My World 2015 au Sénégal: Les priorités de développement des Sénégalais. Ministère du plan Sénégal.

[52] Krishnakumar, J. and Chávez-Juárez, F. (2014) Estimating Capabilities with Structural Equation Models: How Well Are We Doing in a "Real" World? Social Indicators Research, 129, 717-737.

[53] Vinzi, V.E., Trinchera, L. and Amato, S. (2010) PLS Path Modeling: From Founda- 
tions to Recent Developments and Open Issues for Model Assessment and Improvement. In: Vinzi, E., Chin, W.W., Henseler, J. and Wang, H., Eds., Handbook of Partial Least Squares, Springer, Berlin Heidelberg, 47-82. https://doi.org/10.1007/978-3-540-32827-8_3

[54] Wold, H. (1982) Model Construction and Evaluation When Theoretical Knowledge Is Scarce: An Example of the Use of Partial Least Squares. Cahier du Département d'économétrie, Faculté des Sciences Economiques et Sociales, 06, 79, 1982.

[55] Wold, H. (1985) Partial Least Squares. In: Kotz, S. and Johnson, N.L., Eds., Encyclopedia of Statistical Sciences, Vol. 6, John Wiley, New York, 581-591.

[56] ANSD (2013) Rapport définitif de la deuxième Enquête de Suivi de la Pauvreté au Sénégal (ESPS II). Agence Nationale de la Statistique et de la Démographie (ANSD), Dakar.

[57] Tenenhaus, M., Vinzi, V.E., Chatelin, Y.M. and Lauro, C. (2005) PLS Path Modeling. Computational Statistics \& Data Analysis, 48, 159-205. https://doi.org/10.1016/j.csda.2004.03.005

[58] MacKenzie, S.B., Podsakoff, P.M. and Podsakoff, N.P. (2011) Construct Measurement and Validation Procedures in MIS and Behavioral Research: Integrating New and Existing Techniques. MIS Quarterly, 35, 293-334.

[59] Bollen, K.A. (1983) Structural Equations with Latent Variables. John Wiley \& Sons, New York.

[60] Anderson, J.C. and Gerbing, D.W. (1988) Structural Equation Modeling in Practice: A Review and Recommended Two-Step Approach. Psychological Bulletin, 103, 411 423. https://doi.org/10.1037/0033-2909.103.3.411

[61] Nunnally, J.C. (1978) Psychometric Theory. McGraw-Hill, New York.

[62] Nunnally, J.C. and Bernstein, I.H. (1994) The Assessment of Reliability. Psychometric Theory, 3, 248-292.

[63] Chin, W.W. (1998) The Partial Least Squares Approach to Structural Equation Modeling. Modern Methods for Business Research, 2, 295-336.

[64] Fornell, C. and Larcker, D.F. (1981) Evaluating Structural Equation Models with Unobservable Variables and Measurement Error. Journal of Marketing Research, 18, 39-50. https://doi.org/10.2307/3151312

[65] Afthanorhan, W. (2014) Hierarchical Component Using Reflective-Formative Measurement Model in Partial Least Square Structural Equation Modeling (Pls-Sem). International Journal of Mathematics, 2, 33-49.

[66] MacKenzie, S.B., Podsakoff, P.M. and Jarvis, C.B. (2005) The Problem of Measurement Model Misspecification in Behavioral and Organizational Research and Some Recommended Solutions. Journal of Applied Psychology, 90, 710-730. https://doi.org/10.1037/0021-9010.90.4.710

[67] Bollen, K. and Lennox, R. (1991) Conventional Wisdom on Measurement: A Structural Equation Perspective. Psychological Bulletin, 110, 305-314. https://doi.org/10.1037/0033-2909.110.2.305

[68] Fornell, C. and Bookstein, F.L. (1982) Two Structural Equation Models: LISREL and PLS Applied to Consumer Exit-Voice Theory. Journal of Marketing Research, 19, 440-452. https://doi.org/10.2307/3151718

[69] Ringle, C.M., Sarstedt, M. and Straub, D. (2012) A Critical Look at the Use of PLSSEM in MIS Quarterly. MIS Quarterly (MISQ), 36, 3-14.

[70] Geisser, S. (1974) A Predictive Approach to the Random Effect Model. Biometrika, 61, 101-107. https://doi.org/10.1093/biomet/61.1.101

[71] Stone, M. (1974) Cross-Validatory Choice and Assessment of Statistical Predictions. 
Journal of the Royal Statistical Society. Series B (Methodological), 36, 111-147.

[72] Fornell, C. and Cha, J. (1994) Partial Least Squares. Advanced Methods of Marketing Research, 407, 52-78.

[73] Tenenhaus, M., Amato, S. and Vinzi, V.E. (2004) A Global Goodness-of-Fit Index for PLS Structural Equation Modelling. Proceedings of the XLII SIS Scientific Meeting, 1, 739-742.

[74] Wetzels, M., Odekerken-Schröder, G. and Van Oppen, C. (2009) Using PLS Path Modeling for Assessing Hierarchical Construct Models: Guidelines and Empirical Illustration. MIS Quarterly, 31, 177-195. 


\section{Appendix}

Table 1A. Indicators of each dimension or latent variables from ESPS-II dataset.

\begin{tabular}{|c|c|c|c|}
\hline \multicolumn{2}{|c|}{ Capabilities/Well-being } & \multicolumn{2}{|l|}{ Functionings } \\
\hline Dimensions & $\begin{array}{c}\text { Latent } \\
\text { variables }\end{array}$ & Indicators & $\begin{array}{l}\text { Manifest } \\
\text { variables }\end{array}$ \\
\hline \multirow{2}{*}{ Education } & \multirow[t]{2}{*}{ Educat } & Level of studies & nived_cm \\
\hline & & The highest diploma obtained & diplo_cm \\
\hline \multirow[b]{2}{*}{ Health } & \multirow{2}{*}{ Health } & Sick or injured in the past four weeks & eta_sant \\
\hline & & $\begin{array}{c}\text { Consultation with a medical staff or } \\
\text { healer }\end{array}$ & Consul \\
\hline \multirow{2}{*}{ Nutrition } & \multirow[t]{2}{*}{ Nutrition } & $\begin{array}{c}\text { Number of meals per day in normal } \\
\text { times }\end{array}$ & alim_1 \\
\hline & & $\begin{array}{l}\text { Number of meals per day during learn } \\
\text { period }\end{array}$ & $\operatorname{alim} \_2$ \\
\hline \multirow{6}{*}{$\begin{array}{c}\text { Housing } \\
\text { conditions }\end{array}$} & \multirow{6}{*}{ Cond_vie } & Type of housing & typ_log \\
\hline & & Roof materials & mat_toît \\
\hline & & Wall materials & mat-mur \\
\hline & & Type of toilet & typ_toil \\
\hline & & Source of electricity & source_el \\
\hline & & Index quintile of asset equipment & quintile_a \\
\hline \multirow{2}{*}{$\begin{array}{c}\text { Good } \\
\text { governance }\end{array}$} & \multirow[t]{2}{*}{ Bon_gouv } & Appreciation of corruption & aprec_cor \\
\hline & & Appreciation of public embezzlement & aprec_det \\
\hline \multirow{2}{*}{$\begin{array}{c}\text { Non } \\
\text { institutional } \\
\text { support }\end{array}$} & \multirow{2}{*}{ Liens_soc } & Support friends & Soutami \\
\hline & & Support of neighbors & Soutvoiz \\
\hline \multirow{4}{*}{$\begin{array}{l}\text { Economic } \\
\text { subjective } \\
\text { well-being }\end{array}$} & \multirow{3}{*}{ Bien-etre_eco } & Satisfaction by rapport in income & satis_rev \\
\hline & & Perception of the economic situation & prcp_site \\
\hline & & Perception of the membership category & prcp_men \\
\hline & \multirow{5}{*}{ Satis_vie } & Satisfaction with consumption & satis_con \\
\hline \multirow{4}{*}{$\begin{array}{c}\text { Life } \\
\text { satisfaction }\end{array}$} & & Satisfaction with housing & satis_log \\
\hline & & Satisfaction with clothing & satis_hab \\
\hline & & Satisfaction with health & satis_san \\
\hline & & Satisfaction with education & satis_edu \\
\hline $\begin{array}{l}\text { Subjective } \\
\text { well-being }\end{array}$ & SWB & Subjective well-being & Swb \\
\hline
\end{tabular}


Table 2A. Outer model result.

\begin{tabular}{|c|c|c|c|c|c|c|c|}
\hline $\begin{array}{c}\text { Latent } \\
\text { Variables }\end{array}$ & $\begin{array}{l}\text { Manifest } \\
\text { Variables }\end{array}$ & $\begin{array}{c}\text { Alpha } \\
\text { Cronbach }\end{array}$ & $\begin{array}{c}\text { Rho de } \\
\text { D.G. (ACP) }\end{array}$ & Eigenvalues & Loadings & Communalities & $\begin{array}{c}\text { Average } \\
\text { Communalities } \\
\text { (AVE) }\end{array}$ \\
\hline \multirow{2}{*}{ Educat } & nived_cm & \multirow{2}{*}{0.7251} & \multirow{2}{*}{0.8791} & 1.5687 & 0.9135 & 0.8345 & \multirow{2}{*}{0.7820} \\
\hline & diplo_cm & & & 0.4313 & 0.8541 & 0.7295 & \\
\hline \multirow[b]{2}{*}{ Sante } & eta_sant & \multirow{2}{*}{0.7135} & \multirow[b]{2}{*}{0.8747} & 1.5546 & 0.9047 & 0.8184 & \multirow[b]{2}{*}{0.7758} \\
\hline & consul & & & 0.4454 & 0.8563 & 0.7332 & \\
\hline \multirow{2}{*}{ Nutrition } & alim_1 & \multirow{2}{*}{0.6041} & \multirow{2}{*}{0.8347} & 1.4327 & 0.8387 & 0.7035 & \multirow{2}{*}{0.7163} \\
\hline & alim_2 & & & 0.5673 & 0.8539 & 0.7291 & \\
\hline \multirow{6}{*}{ Cond_vie } & typ_log & \multirow{6}{*}{0.8893} & \multirow{6}{*}{0.9158} & 3.8711 & 0.7813 & 0.6105 & \multirow{6}{*}{0.6430} \\
\hline & mat_toit & & & 0.6417 & 0.8507 & 0.7237 & \\
\hline & mat_mur & & & 0.4931 & 0.7604 & 0.5783 & \\
\hline & typ_toil & & & 0.4268 & 0.7692 & 0.5917 & \\
\hline & source_elec & & & 0.3102 & 0.7697 & 0.5924 & \\
\hline & quintile_asset & & & 0.2572 & 0.8727 & 0.7615 & \\
\hline \multirow{3}{*}{ Bien-etre_eco } & satis_rev & \multirow{3}{*}{0.5976} & \multirow{3}{*}{0.7886} & 1.6639 & 0.7750 & 0.6007 & \multirow{3}{*}{0.5453} \\
\hline & prcp_sitemen & & & 0.7294 & 0.5836 & 0.3406 & \\
\hline & prcp_menap & & & 0.6066 & 0.8335 & 0.6948 & \\
\hline \multirow{2}{*}{ Bon_gouv } & aprec_cor & \multirow{2}{*}{0.8728} & \multirow{2}{*}{0.9402} & 1.7742 & 0.9626 & 0.9265 & \multirow{2}{*}{0.8835} \\
\hline & aprec_det & & & 0.2258 & 0.9168 & 0.8405 & \\
\hline \multirow{2}{*}{ Liens_soc } & soutami & \multirow{2}{*}{0.5796} & \multirow{2}{*}{0.8263} & 1.4081 & 0.5575 & 0.3108 & \multirow{2}{*}{0.6409} \\
\hline & soutvoiz & & & 0.5919 & 0.9854 & 0.9710 & \\
\hline \multirow{5}{*}{ Satis_vie } & satis_consal & & & 3.1645 & 0.8034 & 0.6455 & \multirow{5}{*}{0.6326} \\
\hline & satis_log & & & 0.5579 & 0.7794 & 0.6074 & \\
\hline & satis_hab & 0.8546 & 0.8960 & 0.4541 & 0.8320 & 0.6922 & \\
\hline & satis_sant & & & 0.4345 & 0.8175 & 0.6684 & \\
\hline & satis_educ & & & 0.3890 & 0.7412 & 0.5494 & \\
\hline SWB & Swb & & & & 1.0000 & & \\
\hline & eta_sant & & & 1.5743 & 0.5934 & 0.3521 & \\
\hline Sant & Consul & & & 1.4153 & 0.4895 & 0.2396 & 03812 \\
\hline & alim_1 & & & 0.5668 & 0.6674 & 0.4454 & 0.0012 \\
\hline & alim_2 & & & 0.4437 & 0.6982 & 0.4875 & \\
\hline
\end{tabular}

Source: authors, from XLSTAT-PLSPM. 
Table 3A. Test for discriminant validity.

\begin{tabular}{ccccccccccccc}
\hline & Educat & Sante & Nutrition & \multicolumn{2}{l}{ Cond_vie } & \multicolumn{2}{l}{ Sant-corps } & Bien-etre_eco Bon_gouv & Liens_soc & Satis_vie & SWB & AVE \\
\hline Educat & 1 & 0.00 & 0.00 & 0.15 & 0.00 & 0.06 & 0.00 & 0.02 & 0.07 & 0.00 & 0.7820 \\
Sante & 0.00 & 1 & 0.00 & 0.00 & 0.38 & 0.00 & 0.00 & 0.00 & 0.00 & 0.00 & 0.7758 \\
Nutrition & 0.00 & 0.00 & 1 & 0.01 & 0.65 & 0.04 & 0.00 & 0.00 & 0.02 & 0.02 & 0.7163 \\
Cond_vie & 0.15 & 0.00 & 0.01 & 1 & 0.01 & 0.12 & 0.03 & 0.05 & 0.13 & 0.03 & 0.6430 \\
Sant-corps & 0.00 & 0.38 & 0.65 & 0.01 & 1 & 0.03 & 0.00 & 0.00 & 0.01 & 0.02 & 0.3812 \\
Bien-etre_eco & 0.06 & 0.00 & 0.04 & 0.12 & 0.03 & 1 & 0.00 & 0.01 & 0.46 & 0.07 & 0.5453 \\
Bon_gouv & 0.00 & 0.00 & 0.00 & 0.03 & 0.00 & 0.00 & 1 & 0.00 & 0.00 & 0.00 & 0.8835 \\
Liens_soc & 0.02 & 0.00 & 0.00 & 0.05 & 0.00 & 0.01 & 0.00 & 1 & 0.01 & 0.00 & 0.6409 \\
Satis_vie & 0.07 & 0.00 & 0.02 & 0.13 & 0.01 & 0.46 & 0.00 & 0.01 & 1 & 0.04 & 0.6326 \\
SWB & 0.00 & 0.00 & 0.02 & 0.03 & 0.02 & 0.07 & 0.00 & 0.00 & 0.04 & 1 \\
\hline
\end{tabular}

Source: authors, from XLSTAT-PLSPM.

Table 4A. Test of validity for second order variable: "Sant-corps".

\begin{tabular}{ccc}
\hline Statistic & Sante & Nutrition \\
\hline $\mathrm{R}^{2}$ & 0.0014 & 0.0014 \\
Tolérancy & 0.9986 & 0.9986 \\
VIF & 1.0014 & 1.0014 \\
\hline
\end{tabular}

Source: authors, from XLSTAT-PLSPM.

\section{Scientific Research Publishing}

Submit or recommend next manuscript to SCIRP and we will provide best service for you:

Accepting pre-submission inquiries through Email, Facebook, LinkedIn, Twitter, etc. A wide selection of journals (inclusive of 9 subjects, more than 200 journals)

Providing 24-hour high-quality service

User-friendly online submission system

Fair and swift peer-review system

Efficient typesetting and proofreading procedure

Display of the result of downloads and visits, as well as the number of cited articles

Maximum dissemination of your research work

Submit your manuscript at: http://papersubmission.scirp.org/

Or contact me@scirp.org 